\title{
HIV controllers: state of the art
}

Olivier Lambotte

From $16^{\text {th }}$ International Symposium on HIV and Emerging Infectious Diseases

Marseille, France. 24-26 March 2010

HIV controllers are rare chronically HIV-1-infected patients in whom viral replication is undetectable in the absence of antiretroviral treatment. Most such patients are nonetheless infected by replication-competent viruses. An effective multifunctional HIV-specific CD8+ $\mathrm{T}$ cell response and functional CD4 $\mathrm{T}$ cells are thought to be central to viral control in these individuals. The mechanisms underlying this spontaneous control of HIV infection are the focus of intensive investigations, as they should help to unravel the pathogenesis of AIDS and to provide new clues for the design of effective vaccine strategies. In this review we examine recent findings from these studies.

Published: 11 May 2010

doi:10.1186/1742-4690-7-S1-I26

Cite this article as: Lambotte: HIV controllers: state of the art.

Retrovirology 2010 7(Suppl 1):126.

- Convenient online submission

- Thorough peer review

- No space constraints or color figure charges

- Immediate publication on acceptance

- Inclusion in PubIMed, CAS, Scopus and Google Scholar

- Research which is freely available for redistribution 